\title{
PENGEMBANGAN MODEL EVALUASI PROSES PEMBELAJARAN MATEMATIKA DI SMP BERDASARKAN KURIKULUM 2013
}

\author{
1) Sugiyanto, 2)Badrun Kartowagiran, 3)Jailani \\ 1)LPMP Provinsi Kalimantan Tengah, 2, 3)Universitas Negeri Yogyakarta \\ 1)sugi_kalteng58@yahoo.com, 2)badrunkw@yahoo.com,3)jailani_uny@yahoo.com
}

\section{Abstrak}

Penelitian ini bertujuan mengembangkan model evaluasi proses pembelajaran matematika di SMP berdasarkan Kurikulum 2013, dan menilai keefektifan model yang dikembangkan. Penelitian ini menggunakan metode penelitian dan pengembangan. Subjek coba adalah guru, kepala sekolah, dan pengawas. Instrumen pengumpul data adalah kuesioner dan lembar observasi. Proses pengembangan dilakukan dalam 4 tahap yaitu: (1) investigasi awal; (2) perencanaan pengembangan, validasi; (3) uji coba, dan (4) finalisasi produk. Uji coba dilakukan tiga tahap dengan jumlah subjek meningkat setiap tahapnya. Instrumen evaluasi terdiri instrumen penilaian perencanaan pembelajaran, pelaksanaan pembelajaran, dan pelaksanaan penilaian. Validitas isi dilakukan melalui focus group discussion (FGD). Validitas konstruk dilakukan dengan menggunakan analisis faktor, dan estimasi reliabilitasnya mengunakan Intraclass Correlation Coefficient (ICC). Hasil penelitian berupa model evaluasi proses pembelajaran matematika di SMP, yaitu prosedur evaluasi, panduan evaluasi, dan instrumen evaluasi. Berdasarkan hasil uji coba, semua instrumen memiliki kecocokan model yang baik, karena validitas konstruk, dan reliabilitas memenuhi persyaratan akademik. Penilaian para praktisi dan pengguna, model evaluasi proses pembelajaran matematika sangat efektif untuk diterapkan.

Kata kunci: model evaluasi, proses pembelajaran, matematika SMP

\section{DEVELOPING A MODEL FOR AN EVALUATION OF MATHEMATICS LEARNING PROCESSES AT JUNIOR HIGH SCHOOLS BASED ON CURRICULUM 2013}

\author{
1) Sugizanto, 2)Badrun Kartowagiran, 3)Jailani \\ 1)LPMP Provinsi Kalimantan Tengah, 2, 3)Universitas Negeri Yogyakarta \\ ${ }^{1)}$ sugi_kalteng58@yahoo.com, 2)badrunkw@yahoo.com, 3)jailani_uny@yahoo.com
}

\begin{abstract}
This studi aims to develop a model for an evaluation of mathematics learning processes at junior high schools (JHSs) based on Curriculum 2013 and evaluate the effectiveness of the model developed. This was a research and development study. The subject of the research was the teachers, principals, and supervisors. The data collecting instruments were questionnaires and observational sheet. The development process was carried out in 4 stages namely: (1) preliminary investigation; (2) planning development, validation; (3) tryout; (4) product finalization. The try out was performed in 3 stages with the increasing number of participants for each stage. The learning process evaluation model was supported by instrument to assess lesson plans, learning implementation, and the implementation of learning outcome assessment. The content validity was assessed through focus group discussion (FGD). The construct validity was assessed by the factor analysis, and the reliabilities were estimated by the Intraclass Correlation Coefficient (ICC). The result of the research was a model of evaluation of mathematics learning processes at junior high schools (JHSs) based on Curriculum 2013, consisting of procedures, evaluation guideline and the well designed instruments. Based on the try out, all of the instruments have had good suitability, because construct validity and reliability meet all of the academic requirements. According to the evaluation from the practitioners and the model users, the model of the evaluation of mathematics learning processes at junior high schools (JHSs) based on Curriculum 2013 was very effective to be implemented.
\end{abstract}

Keywords: development model, evaluation of learning processes, SMP mathematics 


\section{Pendahuluan}

Pembelajaran matematika berdasarkan Kurikulum 2013 mulai dilaksanakan pada tahun pelajaran 2013/2014 di sekolah, dari jenjang pendidikan dasar sampai dengan jenjang pendidikan menengah di seluruh Indonesia. Adapun kompetensi lulusannya menekankan pada ranah sikap, pengetahuan, dan keterampilan yang pelaksanaan dan kriterianya telah diatur dalam Peraturan Menteri Pendidikan dan Kebudayaan (Permendibud) RI No.54 Tahun 2013 tentang Standar Kompetensi Lulusan dan Permendikbud No. 65 Tahun 2013 tentang Standar Proses. Untuk dapat mewujudkan ketercapaian ketiga ranah tersebut, setiap sekolah pada semua jenjang pendidikan dalam pelaksanaan kegiatan pembelajarannya harus mengacu pada standar yang telah ditetapkan, baik pembelajaran yang dilakukan di kelas maupun pembelajaran yang dilakukan di luar kelas dalam lingkungan sekolah.

Pengertian pembelajaran menurut Nitko \& Brookhart (2007, p.18), merupakan proses yang digunakan untuk mengarahkan peserta didik dengan kondisi membantu mereka mencapai target belajar. Hal senada disampaikan oleh Suherman (2003, p.7) bahwa pembelajaran merupakan upaya penataan lingkungan yang memberi nuansa agar program belajar tumbuh dan berkembang secara optimal. Martiyono (2012, p.12) menambahkan bahwa pembelajaran merupakan kegiatan melaksanakan rencana pembelajaran untuk mencapai tujuan, sehingga proses pembelajaran berjalan secara baik dan mencapai hasil yang optimal. Dalam pembelajaran, guru memiliki peran penting dalam mengkondisikan lingkungan agar menunjang terjadinya perubahan perilaku bagi peserta didik (Darmadi, 2010, pp.177-178). Kegiatan pembelajaran yang dilakukan di sekolah, menurut Permendikbud No.65 tentang Standar Proses, diawali dengan kegiatan penyusunan perencanaan pembelajaran, pelaksanaan proses pembelajaran, dan selanjutnya dilakukan penilaian hasil belajar.

Perencanaan pembelajaran dirancang dalam bentuk Silabus dan Rencana Pelaksanaan Pembelajaran (RPP). Silabus meru- pakan acuan penyusunan RPP. Rencana pelaksanaan pembelajaran dikembangkan dari silabus untuk mengarahkan kegiatan pembelajaran peserta didik dalam upaya mencapai Kompetensi Dasar (KD). Perencanaan pembelajaran menurut Martiyono (2012, p.22) adalah kegiatan merencanakan semua komponen pembelajaran dan langkah-langkahnya yang akan dilaksanakan untuk mencapai tujuan, sehingga proses pembelajaran berjalan secara baik dan mencapai hasil yang optimal. Hal ini juga dinyatakan oleh Uno (2008, p.2) yang menyebutkan bahwa, perencanaan adalah cara membuat kegiatan berjalan dengan baik, disertai berbagai langkah yang antisipatif guna memperkecil kesenjangan yang terjadi sehingga kegiatan dapat mencapai tujuan yang telah ditetapkan. Perencanaan pembelajaran dirancang dalam bentuk silabus RPP, yang dilengkapi dengan pemanfaatan media dan bahan ajar. Menurut Majid (2008, p.38) silabus adalah rancangan pembelajaran yang berisi rencana bahan ajar mata pelajaran tertentu. Dijelaskan pula oleh Darling, (2010, p.11), bahwa silabus adalah titik penting dari interaksi antara guru dengan peserta didik baik di dalam ataupun di luar kelas. Silabus perlu disusun agar hasil pembelajaran sesuai dengan keluaran yang diharapkan. Daley (2010, p.166), mengatakan, silabus perlu diorganisasi sehingga setiap hasil belajar memiliki hasil secara pasti. Silabus adalah penjabaran SK dan KD ke dalam materi pokok, kegiatan pembelajaran, indikator, penilaian, alokasi waktu, sumber belajar. Hal senada disampaikan oleh Rusman (2012, p.6) bahwa silabus adalah rencana pembelajaran pada suatu kelompok mata pelajaran tertentu yang mencakup SK, KD, materi pokok, pembelajaran, indikator, penilaian, alokasi waktu, dan belajar.

Proses pembelajaran merupakan implementasi dari rencana pembelajaran yang meliputi kegiatan pendahuluan, inti dan penutup. Kegiatan pendahuluan meliputi penyiapan peserta didik oleh guru secara psikis dan fisik untuk mengikuti pembelajaran, memberi motivasi, mengajukan pertanyaan berkaitan pengetahuan sebelumnya dengan 
materi yang akan dipelajari, menjelaskan tujuan, dan menyampaikan cakupan materi. Pada kegiatan inti, guru menggunakan model dan metode, media, sumber belajar sesuai dengan karakteristik peserta didik dan mata pelajaran. Pada kegiatan penutup, dilakukan refleksi untuk mengevaluasi seluruh rangkaian aktivitas pembelajaran dan hasilhasil yang diperoleh dan menemukan manfaat dari hasil pembelajaran. Untuk mengetahui perolehan hasil belajar, guru melakukan penilaian hasil belajar peserta didik.

Penilaian hasil belajar peserta didik diatur melalui Kemendikbud Nomor 66 Tahun 2013 yaitu mencakup kompetensi sikap, pengetahuan dan keterampilan. Penilaian sikap dilakukan melalui observasi, penilaian diri, penilaian teman sejawat dan jurnal. Instrumen yang digunakan untuk observasi, penilaian diri, dan penilaian antarpeserta didik adalah daftar cek atau skala penilaian yang disertai rubrik, sedangkan penilaian melalui jurnal berupa catatan dari pendidik. Penilaian kompetensi pengetahuan dilakukan pendidik melalui tes tulis, tes lisan, dan penugasan. Penilaian kompetensi keterampilan, dilakukan pendidik melalui penilaian kinerja, yaitu penilaian yang menuntut peserta didik mendemonstrasikan suatu kompetensi tertentu dengan menggunakan tes praktik, projek, dan penilaian portofolio.

Dalam Permendikbud No. 68 Tahun 2013 disebutkan bahwa matematika merupakan salah satu mata pelajaran yang wajib diberikan di SMP. Proses pembelajaran matematika di SMP berdasarkan Kurikulum 2013 menggunakan pendekatan saintifik sebagaimana tertuang pada Lampiran IV Permendikbud Nomor 81A, yaitu melalui kegiatan: (1) mengamati; (2) menanya; (3) mengumpulkan informasi; (4) mengasosiasi; dan (5) mengkomunikasikan. Kompetensi yang dikembangkan adalah melatih kesungguhan, ketelitian, dan mencari informasi. Kegiatan penilaian mengacu pada Permendikbud No. 66 Tahun 2013 tentang Standar Penilaian, yang mencakup penilaian sikap, penilaian pengetahuan dan penilaian keterampilan. Untuk dapat mengetahui efektivi- tas pelaksanaan proses pembelajaran matematika di setiap satuan pendidikan secara komprehensif, perlu dilakukan kegiatan evaluasi.

Seiring dengan pelaksanaan Kurikulum 2013 di sekolah, peneliti melakukan observasi ke sekolah SMP di Provinsi Kalimantan Tengah yang telah melaksanakan Kurikulum 2013. Observasi dilakukan di 4 sekolah SMP yang berada di Kota Palangkaraya, yaitu SMP Negeri 1 Palangkaraya, SMP Negeri 2 Palangkaraya, SMP Negeri 3 Palangkaraya dan SMP Nahdatul Ulama Palangkaraya. Tujuannya adalah untuk memperoleh informasi berkaitan dengan pelaksanaan evaluasi pembelajaran matematika di SMP berdasarkan Kurikulum 2013. Observasi dilakukan pada pelaksanaan pembelajaran yang meliputi kegiatan perencanaan pembelajaran, kegiatan proses pembelajaran, dan kegiatan pelaksanaan penilaian hasil belajar.

Kegiatan observasi perencanaan pembelajaran dilakukan melalui studi dokumentasi terkait dengan keberadaan silabus, RPP, dan bahan ajar. Kegiatan observasi pada pelaksanaan proses pembelajaran dilakukan dengan mengamati secara langsung pelaksanaan pembelajaran yang dilakukan guru di kelas. Pengamatan difokuskan pada penataan tempat duduk peserta didik yang memungkinkan peserta didik untuk melakukan diskusi kelas, kegiatan pendahuluan, kegiatan inti, dan kegiatan penutup di kelas. Kegiatan observasi pada pelaksanaan pengolahan dan pelaporan hasil belajar peserta didik dilakukan melalui wawancara dan studi dokumentasi. Kegiatan difokuskan pada adanya dokumen perencanaan penilaian hasil belajar dan buku laporan hasil penilaian yang dibuat oleh guru. Pelaksanaan penilaian dilakukan melalui pengamatan pada akhir pembelajaran setelah satu bahasan selesai dilaksanakan pembelajaran.

Berdasarkan hasil observasi diperoleh data sebagai berikut. (1) Sekolah belum melakukan evaluasi proses pembelajaran matematika sesuai Kurikulum 2013, disebabkan karena sekolah belum memiliki instrumen dan panduan pelaksanaan evaluasi proses 
pembelajaran. (2) Silabus yang seyogyanya telah dipersiapkan oleh pemerintah, tetapi pada saat dilakukan pengamatan, silabus masih dalam bentuk draf yang tingkat keterbacaannya masih sulit dipahami oleh guru. (3) Rencana pelaksanaan pembelajaran yang dipersiapkan guru masih menggunakan contoh yang diperoleh pada waktu guru mengikuti pelatihan implementasi kurikulum. (4) Bahan ajar belum disusun oleh guru karena guru masih mengalami kesulitan dalam melakukan telaah buku paket matematika yang telah disediakan oleh pemerintah. (5) Penataan ruang kelas belum mengarah pada pembelajaran dengan pendekatan saintifik. (6) Guru belum memiliki perangkat perencanaan penilaian berdasarkan Kurikulum 2013, hal ini disebabkan karena guru belum memahami komponen-komponen yang harus dipersiapkan dalam perencanaan penilaian hasil belajar peserta didik, belum memahami cara melakukan penilaian serta belum memahami cara pengolahan dan pelaporan hasil belajar peserta didik. Hal ini senada dengan penelitian Kartowagiran, dkk (2013), bahwa kepala SMP di DIY siap melaksanakan implementasi Kurikulum 2013, namun guru belum siap melaksanakan implementasi Kurikulum 2013.

Selanjutnya, melalui diskusi dengan pengawas sekolah, diperoleh informasi bahwa: (1) aktivitas pembelajaran belum teramati secara optimal; (2) fungsi kepengawasan masih menekankan pada kelengkapan administrasi yang dimiliki guru; (3) sekolah belum memiliki instrumen evaluasi pelaksanaan pembelajaran berdasarkan $\mathrm{Ku}-$ rikulum 2013; (4) sekolah belum memiliki model laporan evaluasi pembelajaran menurut Kurikulum 2013.

Berkaitan dengan kegiatan evaluasi, Kaufman \& Thomas (1980, p.4) menyatakan, evaluasi adalah suatu proses untuk menilai kualitas sesuatu yang sedang berlangsung. Menurut Gronlund \& Linn (1985, p.5), evaluasi adalah proses yang sistematis yang bertujuan mengumpulkan informasi, diinterpretasi guna mengetahui tingkat keberhasilan sasaran. Fitzpatrick, Sander \& Worthen (2011, p.7) menyatakan Salah satu kegiatan evaluasi yang terpenting adalah membantu stakeholder mengambil keputusan yang telah dikaji kekurangan dan kelebihannya dalam mengambil keputusan. Proses pelaksanaan evaluasi membutuhkan dukungan dan kerja sama dari semua pihak pendidikan (Hood \& Hopson (2008, p.416). Stufflebeam, Madaus, \& Kellaghan (2002, pp.19-20) menyatakan model adalah suatu rancangan yang dibuat untuk melatih atau membentuk seseorang untuk memiliki suatu cara atau gaya hidup tertentu. Model evaluasi menurut Stufflebeam, Madaus, \& Kellaghan (2000, pp.119-120) dalah model yang menggambarkan pandangan pembuat model konsep dan struktur dalam melakukan evaluasi, sekaligus menyediakan pedoman evaluasi menggunakan model yang dirancang untuk mendeskripsikan, memberi penilaian dan rekomendasi. Sehubungan hal tersebut, penelitian ini mengembangkan sebuah model evaluasi pembelajaran matematika di SMP berdasarkan Kurikulum 2013.

Model evaluasi yang dikembangkan meliputi prosedur pelaksanaan evaluasi, instrumen evaluasi pembelajaran, dan panduan pelaksanaan evaluasi. Model evaluasi proses pembelajaran ini diharapkan dapat memberikan informasi secara komprehensif dan representatif tentang pelaksanaan pembelajaran matematika yang dilakukan guru di sekolah. Model evaluasi yang dikembangkan mengacu pada Permendikbud No.65 tentang Standar Proses, Permendikbud No. 66 tentang Standar Penilaian, dan Permendikbud No.81A tentang Implementasi Kurikulum.

\section{Metode Penelitian}

Penelitian ini merupakan penelitian pengembangan (research and development) bertujuan untuk menghasilkan suatu produk berupa sebuah model evaluasi proses pembelajaran matematika di SMP berdasarkan Kurikulum 2013. Model penelitian yang digunakan mengacu pada desain model yang dikembangkan oleh Borg \& Gall (1983, p.775) dengan 10 langkah, yang disederhanakan peneliti menjadi 4 langkah/tahapan yaitu: (1) tahap studi pendahuluan, (2) tahap

Pengembangan Model Evaluasi Proses Pembelajaran ... -

Sugiyanto, Badrun Kartowagiran, Jailani 
perencanaan pengembangan, (3) tahap uji coba, evaluasi, revisi, dan (4) tahap implementasi.

Pada tahap awal dilakukan studi pendahuluan, yaitu untuk memperoleh data berkaitan dengan pelaksanaan evaluasi pembelajaran di sekolah. Selanjutnya, dilakukan kajian teori berkaitan pembelajaran matematika di SMP, mengkaji model-model evaluasi, dan mengkaji hasil penelitian terdahulu yang relevan. Data dari hasil studi pendahuluan dijadikan acuan untuk menyusun perencanaan pengembangan. Pada tahap perencanaan, pengembangan disusun desain model evaluasi proses pembelajaran yang terdiri dari prosedur evaluasi, komponen evaluasi, instrumen, panduan, dan desain uji cobanya. Selanjutnya, semua hasil perencanaan dikaji keterbacaan oleh pakar dan praktisi melalui focus group discusion (FGD). Pelaksanaan FGD dilakukan oleh 7 orang pakar (dosen) dan 20 orang widyaiswara LPMP. Uji keterbacaan dilakukan oleh 12 orang guru, 5 orang kepala sekolah SMP, 20 orang pengawas. Pada tahap uji coba, evaluasi, dan revisi dilakukan uji coba model, untuk mengetahui sejauhmana instrumen dan panduan dapat mengevaluasi pelaksanaan pembelajaran. Data hasil uji coba dianalisis apakah model sudah baik atau masih perlu diperbaiki. Setelah Instrumen dan panduan sudah baik selanjutnya diimplementasikan ke sekolah. Implementasi dilakukan pada bulan Maret-April 2014. Implementasi dilakukan melalui pengamatan pembelajaran di sekolah, meliputi pengamatan perencanaan, pelaksanaan, dan penilaian hasil belajar matematika di kelas. Hasil pengamatan kemudian diinformasikan kepada guru matematika yang telah diamati. Hasil dari semua tahapan implementasi adalah model evaluasi proses pembelajaran matematika di SMP berdasarkan Kurikulum 2013.

Penelitian pengembangan ini dilakukan pada bulan Juli sampai dengan Oktober 2013. Penelitian dilakukan di sekolah SMP yang pada tahun ajaran 2013/2014 melaksanakan pembelajaran berdasarkan Kurikulum 2013 di wilayah Provinsi Kalimantan Tengah.
Subjek penelitian adalah guru mata pelajaran matematika di SMP yang mulai tahun ajaran 2013/2014 melaksanakan pembelajaran matematika berdasarkan Kurikulum 2013, kepala sekolah SMP yang tergabung pada kelompok kerja kepala sekolah (KKKS), dan pengawas sebagai pembina di sekolah SMP di Provinsi Kalimantan Tengah.

Prosedur pengembangan yang ditempuh dalam penelitian ini adalah dimulai dengan penyusunan desain model evaluasi proses pembelajaran matematika berdasarkan Kurikulum 2013 dan perangkat model evaluasi, dilanjutkan dengan validasi pakar, uji coba, analisis data, dan implementasi hasil.

Penyusunan desain model evaluasi diawali dengan perencanaan model evaluasi yaitu evaluasi perencanaan pembelajaran, evaluasi pelaksanaan pembelajaran, dan evaluasi penilaian hasil belajar peserta didik. Evaluasi perencanaan pembelajaran meliputi kualitas silabus, kualitas RPP, dan kualitas bahan ajar. Evaluasi pelaksanaan pembelajaran meliputi kualitas kegiatan pendahuluan, kegiatan inti, dan penutup. Evaluasi penilaian hasil belajar meliputi kualitas perencanaan penilaian, pelaksanaan penilaian, pengolahan dan pelaporan hasil penilaian. Berdasarkan komponen-komponen tersebut disusun instrumen, prosedur, dan panduannya. Semua instrumen menggunakan skala Likert dengan 4 pilihan. Model evaluasi ini merupakan modifikasi model CIPP dan Kirkpatrick, yang menekankan pada komponen proses pembelajaran. Desain prosedur, instrumen, dan panduan penggunaan model evaluasi proses pembelajaran matematika yang disusun merupakan draf awal dari model yang dikembangkan.

Setelah prosedur evaluasi, instrumen dan panduan pelaksanaan evaluasi pembelajaran disusun, selanjutnya divalidasi dan dilakukan uji keterbacaan oleh para ahli (expert judgement) yaitu dari akademisi atau dosen, dan praktisi yaitu guru, kepala sekolah, pengawas, dan widyaiswara. Proses validasi dilakukan melalui FGD (focus group discussion), bertujuan mengetahui validitas in- 
strumen, kejelasan prosedur, kekomprehensifan komponen, dan kejelasan panduan. Instrumen dinilai berdasarkan kejelasan petunjuk, cakupan isi, bahasa baku, dan tata tulis. Panduan evaluasi dinilai berdasarkan kejelasan dan aspek bahasa. Berdasar hasil penilaian melalui FGD dan uji keterbacaan, selanjutnya disusun desain model evaluasi.

Instrumen dan panduan evaluasi proses pembelajaran yang telah direvisi berdasarkan penilaian dan masukan yang diperoleh dari FGD, selanjutnya diujicobakan di beberapa sekolah. Subjek coba penelitian adalah terdiri dari guru matematika SMP, kepala sekolah SMP, dan pengawas di Provinsi Kalimantan Tengah. Uji coba dilakukan untuk mengetahui kesesuaian model evaluasi, ketepatan model evaluasi, kemudahan penggunaan model evaluasi, dan efisiensi pelaksanaan model evaluasi. Panduan model evaluasi proses pembelajaran matematika divalidasi dari segi kepraktisan penggunaan, kejelasan instrumen evaluasi, dan kesesuaian dengan Bahasa Indonesia yang baik dan benar. Uji coba instrumen dilakukan sebanyak tiga tahap dengan jumlah subjek berturut-turut 90 orang, 150 orang, 240 orang terdiri guru matematika, kepala sekolah SMP, dan pengawas. Data dari hasil uji coba dianalisis untuk membuktikan validitas dan mengestimasi reliabilitasnya. Data tentang kejelasan prosedur evaluasi, kekomprehensifan komponen model, kejelasan instrumen, dan kejelasan panduan evaluasi dianalisis secara deskriptif. Data pelaksanaan proses yang diperoleh melalui pengamatan pembelajaran dianalisis menggunakan teknik inter-rater untuk mengetahui reliabilitasnya. Pengamatan proses pembelajaran matematika di kelas dilakukan oleh dua orang rater yang terdiri dari kepala sekolah/wakil kepala sekolah, pengawas satuan pendidikan, atau guru senior.

Hasil akhir model evaluasi proses pembelajaran matematika yang telah dianalisis, merupakan prototype model evaluasi proses pembelajaran matematika di SMP yang baik. Selanjutnya, model evaluasi proses pembelajaran matematika dikemas dan dilakukan implementasi model ke beberapa sekolah SMP di Provinsi Kalimantan Tengah yang telah melaksanakan kegiatan proses pembelajaran matematika dengan menggunakan Kurikulum 2013. Prototype dalam hal ini adalah instrumen evaluasi perencanaan pembelajaran matematika, instrumen evaluasi pelaksanaan pembelajaran matematika, instrumen evaluasi pelaksanaan penilaian hasil belajar matematika peserta didik, dan panduan penggunaan model evaluasi pembelajaran matematika yang telah diujicobakan dan divalidasi oleh para pakar, praktisi, dan pengguna model evaluasi proses pembelajaran matematika di SMP.

Produk model evaluasi proses pembelajaran matematika SMP yang diuji coba adalah draf model evaluasi yang terdiri dari instrumen evaluasi pelaksanaan proses pembelajaran matematika, dan panduan pelaksanaan evaluasi. Uji coba dimaksudkan untuk memperoleh data secara lengkap sebagai bahan perbaikan produk.

Instrumen yang diujicobakan yaitu instrumen evaluasi perencanaan pembelajaran matematika, instrumen evaluasi pelaksanaan pembelajaran, dan instrumen evaluasi pelaksanaan penilaian hasil belajar peserta didik. Uji coba dilakukan untuk membuktikan validitas, mengestimasi reliabilitas, dan mengetahui tingkat kesepakatan antar-rater. Kejelasan instrumen dilihat dari: petunjuk instrument evaluasi, cakupan kualitas pembelajaran yang dievaluasi, bahasa baku yang digunakan, dan tata tulis. Cakupan kualitas proses pembelajaran adalah: perencanaan pembelajaran, pelaksanaan proses pembelajaran, dan penilaian hasil belajar peserta didik. Penilaian aspek bahasa diarahkan pada: (1) pernyataan yang komunikatif, dan (2) penggunaan kata dan kalimat yang mudah dipahami. Penilaian tata tulis instrumen diarahkan pada bentuk huruf, ukuran huruf dan format atau layout instrumen evaluasi.

Uji kejelasan instrumen evaluasi proses pembelajaran matematika difokuskan pada penilaian terhadap: (1) kejelasan petunjuk instrumen hasil pembelajaran matematika; (2) indikator penilaian sikap, penilaian pengetahuan, dan penilaian keterampilan matematika peserta didik, (3) pernyataan 
yang komunikatif, (4) penggunaan kalimat yang mudah untuk dipahami, dan (5) penilaian tata tulis pada instrumen evaluasi hasil pembelajaran matematika di SMP berdasarkan Kurikulum 2013.

Penilaian panduan penggunaan model evaluasi difokuskan pada aspek isi panduan dan bahasa yang digunakan. Penilaian isi panduan meliputi: (1) kejelasan petunjuk pelaksanaan evaluasi; (2) langkah-langkah kegiatan evaluasi; (3) kejelasan arah dan tujuan rekomendasi hasil evaluasi; dan (4) kejelasan waktu pelaksanaan evaluasi. Penilaian aspek bahasa diarahkan pada: (1) perumusan pada pernyataan yang komunikatif; dan 2) penggunaan kalimat yang mudah dipahami oleh pengguna model evaluasi. Langkah-langkah yang dilakukan pada uji coba adalah: (1) penjelasan tentang konsep model evaluasi pembelajaran matematika, dan naskah konsep model yang akan dikembangkan kepada pengguna model; (2) kejelasan pengguna model evaluasi dalam mempelajari kelengkapan konsep, dan memberikan saran dan masukan atas kekurangan pada model yang akan dikembangkan.

Subjek coba dalam penelitian ini adalah guru matematika SMP, kepala sekolah, dan pengawas yang melaksanakan kurikulum 2013. Adapun data yang diambil adalah data kuantitatif yang diubah menjadi data kualitatif. Data meliputi: (a) data model evaluasi yang meliputi: objektivitas model evaluasi pembelajaran, kepraktisan model evaluasi pembelajaran dan efisiensi model evaluasi pembelajaran; (b) data panduan evaluasi pembelajaran meliputi: kelengkapan panduan evaluasi pembelajaran dan kejelasan panduan evaluasi pembelajaran, (c) data kualitas pelaksanaan pembelajaran SMP meliputi: kualitas silabus, bahan ajar, RPP, kualitas kegiatan awal, kegiatan inti, dan kualitas kegiatan akhir, kualitas perencanaan penilaian, kualitas pelaksanaan penilaian, dan kualitas pelaksanaan pengolahan dan pelaporan hasil penilaian.

Dalam penelitian ini, instrumen pengumpul data terdiri atas: (a) panduan wawancara (b) angket/kuesioner, (c) lembar observasi, dan (d) dokumentasi. Wawancara dilakukan pada tahap studi pendahuluan, untuk memperoleh informasi mengenai pelaksanaan evaluasi proses pembelajaran matematika di SMP. Wawancara dilakukan pada guru matematika SMP, kepala sekolah, dan pengawas sekolah. Selain itu, wawancara juga digunakan untuk mendapatkan informasi yang mendalam pada forum diskusi dengan pakar, praktisi, dan guru mengenai model evaluasi beserta perangkatnya. Observasi dilakukan untuk melengkapi data hasil wawancara. berkaitan pelaksanaan evaluasi pembelajaran. Kegiatan observasi dilakukan pada pelaksanaan proses pembelajaran yang dilakukan oleh guru matematika di kelas. Selain itu, observasi juga dilakukan pada keterlaksanaan model yang dikembangkan mulai dari: (1) persiapan pembelajaran; (2) pelaksanaan pembelajaran; dan (3) penarikan kesimpulan hasil. Observasi dilaksanakan di kelas pembelajaran yang dilakukan guru, diamati oleh teman sejawat, kepala sekolah atau pengawas. Dalam penelitian ini, angket digunakan untuk memperoleh data tentang kejelasan instrumen, dan kejelasan panduan penggunaan model evaluasi pembelajaran yang dikembangkan. Responden adalah guru-guru matematika SMP, kepala sekolah, dan pengawas. Instrumen pengumpul data terdiri dari: (1) instrumen untuk menggali data tentang kejelasan prosedur evaluasi, digunakan kuesioner; (2) instrumen tentang keefektifan model digunakan kuesioner; (3) instrumen tentang kejelasan dan penggunaan panduan evaluasi digunakan kuesioner, (4) instrumen tentang proses pembelajaran di kelas, digunakan observasi, (5) instrumen kejelasan petunjuk, cakupan indikator, penggunaan bahasa, dan tata tulis digunakan kuesioner.

Validitas instrumen meliputi validitas isi dan validitas konstruk. Pembuktian validitas isi dilakukan dengan melalui rational judgement dan expert judgement. Pembuktian validitas konstruk dilakukan dengan menggunakan analisis faktor. Estimasi reliabilitas instrumen evaluasi proses pembelajaran matematika dilakukan melalui pengamatan terhadap perencanaan pembelajaran, pelaksanaan pembelajaran, dan pelaksanaan 
penilaian hasil belajar peserta didik. Teknik yang digunakan untuk menentukan reliabilitas instrumen adalah melalui inter-rater reliability, yaitu kesepakatan (agreement) yang dibuat antar-rater dalam menilai suatu objek (Gwet, 2012, p. 4). Untuk mengukur tingkat kesepakatan antarpenilai (Inter-rater-reliability) dilakukan dengan mengamati koefisien reliabilitas Alpha. Batas bawah koefisien reliabilitas yang digunakan untuk suatu tes yang baik yaitu sebesar 0,70 (Linn, 1989, p.106)

Teknik analisis data menggunakan analisis kuantitatif dan deskriptif kualitatif. Analisis kuantitatif digunakan mengetahui validitas instrumen evaluasi, reliabilitas instrument evaluasi, kecocokan model instrumen, dan keefektifan model. Analisis deskriptif kualitatif digunakan untuk menganalisis prosedur evaluasi, instrumen evaluasi, dan panduan evaluasi. Data dianalisis oleh pakar/ahli, praktisi, dan pengguna model evalusi.

Analisis data kuantitatif digunakan untuk membuktikan validitas dan mengestimasi reliabilitas instrumen. Pemeriksaan validitas dilakukan dengan exploratory factor analysis, reliabilitas dihitung dengan teknik internal consistency, yaitu melihat koefisien Alpha, dengan bantuan SPSS 17.00 for Windows. Pengukuran reliabilitas instrumen pelaksanaan pembelajaran dilakukan dengan teknik interrater reliability. Teknik untuk mengestimasi reliabilitas menggunakan rumus Cohen's Kappa sebagai berikut.

$$
K c=\frac{p a-p e}{1-p e}(\text { Gwet KL, 2012, p.12) }
$$

$$
\begin{aligned}
& P a=\frac{n 11+n 12}{n} \text { dan } \\
& \left.\mathrm{P}_{\mathrm{e}}=[(\mathrm{n} 1+/ \mathrm{n})(\mathrm{n}+1 / \mathrm{n})][\mathrm{n} 2+/ \mathrm{n})(\mathrm{n}+2 / \mathrm{n})\right]
\end{aligned}
$$

Perhitungan reliabilitas instrumen dilakukan dengan bantuan Program SPSS 17.00 for Windows. Pedoman yang digunakan menginterpretasi koefisien Kappa mengacu pada pedoman yang diberikan Fleiss, Levin \& Paik, (2003, p. 604), sebagai berikut.

$$
\begin{array}{ll}
\mathrm{K}>0,75 & : \text { exelent agreement } \\
0,4 \leq \mathrm{K} \leq 0,75 & : \text { fair to good agreement } \\
\mathrm{K}<0,4 & : \text { poor agreement }
\end{array}
$$

Analisis data secara deskriptif kualitatif digunakan dalam menganalisis data hasil validasi dari para ahli. Berdasarkan skor yang diberikan, dicari skor rerata, dikonversi ke skala dan dideskripsikan. Konversi data kuantitatif ke kualitatif merupakan modifikasi dari Sudijono (2011, p.329).

Tabel 1. Konversi Data Kuantitatif ke Data Kualitatif

\begin{tabular}{ccc}
\hline Rumus & Rerata & Klasifikasi \\
\hline $\mathrm{X}>\bar{X}_{l}+1,8 \mathrm{Sb}_{\mathrm{i}}$ & $\mathrm{X}>4,2$ & Sangat Baik \\
$\bar{X}_{l}+0,6 \mathrm{Sb}_{\mathrm{i}}<\mathrm{X} \leq \bar{X}_{l}+1,8 \mathrm{Sb}_{\mathrm{i}}$ & $3,4<\mathrm{X} \leq 4,2$ & Baik \\
$\bar{X}_{l}-0,6 \mathrm{Sb}_{\mathrm{i}}<\mathrm{X} \leq \bar{X}_{l}+0,6 \mathrm{Sb}_{\mathrm{i}}$ & $2,6<\mathrm{X} \leq 3,4$ & Cukup \\
$\bar{X}_{l}-1,8 \mathrm{Sb}_{\mathrm{i}}<\mathrm{X} \leq \bar{X}_{l}-0,6 \mathrm{Sb}_{\mathrm{i}}$ & $1,8<\mathrm{X} \leq 2,6$ & Kurang \\
$\mathrm{X} \leq \bar{X}_{l}-1,8 \mathrm{Sb}_{\mathrm{i}}$ & $\mathrm{X} \leq 1,8$ & Tidak Baik \\
\hline
\end{tabular}

Berdasar rerata skor dan klasifikasi hasil pengembangan tersebut, diadakan penilaian terhadap instrumen, dan panduan model evaluasi sebagai hasil pengembangan dengan dengan standar penilaian disajikan pada Tabel 2 .

Tabel 2. Kriteria Penilaian Instrumen, dan Panduan

\begin{tabular}{cc}
\hline Rerata Skor $(\mathrm{X})$ & Klasifikasi \\
\hline $\mathrm{X}>4,2$ & Sangat Baik \\
$3,4<\mathrm{X} \leq 4,2$ & Baik \\
$2,6<\mathrm{X} \leq 3,4$ & Cukup \\
$1,8<\mathrm{X} \leq 2,6$ & Kurang Baik \\
$\mathrm{X} \leq 1,8$ & Tidak Baik \\
\hline
\end{tabular}

\section{Hasil Penelitian dan Pembahasan}

Tahap Pendahuluan

Kegiatan yang dilakukan meliputi: (1) observasi awal di SMP yang melaksanakan Kurikulum 2013 di Provinsi Kalimantan Tengah, (2) identifikasi masalah di lapangan, (3) kajian pustaka/kajian peraturan pemerintah, dan (4) kajian hasil penelitian yang relevan.

Observasi awal bertujuan untuk mengetahui sejauh mana sekolah telah melaksanakan pembelajaran matematika berdasar- 
kan Kurikulum 2013, pelaksanaan evaluasi pembelajaran. menemukan model evaluasi, dan menetapkan komponen model evaluasi yang dikembangkan.

Identifikasi masalah lapangan diperoleh dari data hasil observasi awal yang dilakukan di beberapa SMP di Provinsi Kalimantan Tengah. Identifikasi masalah yang diperoleh berkaitan dengan pembelajaran matematika adalah: (1) Sekolah belum melakukan evaluasi pembelajaran matematika sesuai Kurikulum 2013; (2) Penataan ruang kelas belum mengarah pada pembelajaran matematika dengan pendekatan saintifik.; (3) Aktivitas pembelajaran matematika yang di lakukan guru di kelas belum teramati secara optimal oleh kepala sekolah ataupun pengawas satuan pendidikan; (4) fungsi kepengawasan masih menekankan kelengkapan administrasi pembelajaran yang dimiliki oleh guru; (5) Evaluasi terhadap kegiatan pembelajaran matematika di kelas belum melibatkan teman sejawat; (6) Sekolah belum memiliki instrumen evaluasi proses pembelajaran matematika; (7) Sekolah belum memiliki model laporan evaluasi proses pembelajaran matematika menurut Kurikulum 2013.

\section{Tahap Perencanaan Pengembangan}

Kajian pustaka dan kajian Peraturan Pemerintah melalui Permendikbud RI Nomor 65 Tahun 2013 tentang Standar Proses, dan Permendikbud Nomor $81 \mathrm{~A}$ tentang Implementasi kurikulum digunakan untuk menyusun sebuah model evaluasi proses pembelajaran matematika di sekolah SMP berdasarkan Kurikulum 2013. Model evaluasi yang disusun meliputi prosedur evaluasi, komponen, indikator dan instrumennya, serta panduan pelaksanaan evaluasi.

Kajian penelitian terdahulu yang relevan digunakan untuk mendukung kelengkapan model evaluasi yang telah disusun. Selanjutnya model evaluasi tersebut divalidasi oleh para pakar melalui Focus Group Discusion (FGD). Hasil diskusi yang dilaksanakan melalui FGD disepakati bahwa ada tiga komponen yang layak untuk dikembangkan dalam evaluasi proses pembelajar- an matematika di SMP yaitu: evaluasi perencanaan pembelajaran, evaluasi pelaksanaan proses pembelajaran, dan evaluasi pelaksanaan penilaian hasil belajar. Setiap komponen disusun subkomponen berdasarkan indikatornya. Subkomponen evaluasi perencanaan meliputi silabus, RPP, dan bahan ajar, subkomponen evaluasi pelaksanaan pem-belajaran meliputi kegiatan awal, inti, dan penutup, dan subkomponen evaluasi pelaksanaan penilaian meliputi evaluasi perencanan penilaian, evaluasi pelaksanaan penilaian, evaluasi pelaksanaan pengolahan dan pelaporan hasil belajar. Setiap subkomponen diuraikan menjadi butir pernyataan yang selanjutnya disusun dalam instrumen-instrumen sesuai dengan bunyi indikatornya.

Sesuai dengan komponen yang telah ditetapkan dalam desain model evaluasi, prosedur evaluasi pembelajaran yang harus diikuti adalah sebagai berikut. Pertama, dilakukan evaluasi perencanaan pembelajaran matematika yang meliputi kualitas silabus, RPP, dan bahan ajar yang telah dipersiapkan guru. Kedua, dilakukan evaluasi terhadap pelaksanaan proses pembelajaran, yang meliputi kegiatan pendahuluan, inti, dan penutup selama pelaksanaan pembelajaran matematika di kelas. Ketiga, dilakukan evaluasi terhadap pelaksanaan penilaian hasil belajar yang meliputi kualitas perencanaan, pelaksanaan penilaian hasil belajar, dan kualitas pengolahan serta pelaporan hasil belajar.

\section{Tahap Uji Coba}

\section{Hasil Uji Keterbacaan}

Uji keterbacaan atau kejelasan perangkat model evaluasi proses pembelajaran matematika didasarkan pada hasil validasi (penilaian) dari para ahli evaluasi (dosen 7 orang), pemakai model evaluasi (kepala sekolah 11 orang, pengawas 20 orang, guru matematika SMP 20 orang), serta praktisi (widyaiswara LPMP Kalimantan Tengah 20 orang), yaitu yang memberikan masukanmasukan dalam rangka perbaikan instrumen. Kejelasan perangkat model evaluasi proses pembelajaran matematika meliputi 
prosedur pelaksanaan evaluasi pembelajaran, instrumen evaluasi pembelajaran, panduan pelaksanaan evaluasi pembelajaran, dan efektivitas model evaluasi proses pembelajaran yang dikembangkan.

\section{Kejelasan Prosedur Evaluasi}

Hasil uji keterbacaan prosedur evaluasi proses pembelajaran disajikan pada Tabel 3. Uji keterbacaan prosedur evaluasi pembelajaran diarahkan pada aspek: (1) kejelasan prosedur evaluasi, (2) keefektifan kalimat yang digunakan, (3) ketepatan ejaan dan tanda baca, (4) kelengkapan komponen evaluasi, (5) kepraktisan prosedur pelaksanaan evaluasi, (6) kepraktisan dan kesederhanaan prosedur penyajiannya, (7) efisien waktu, (8) efisien biaya, (9) efisien tenaga. Penilaian keterbacaan prosedur evaluasi pelaksanaan pembelajaran menggunakan skala 5 .

Tabel 3. Rekapitulasi Hasil Uji Keterbacaan Prosedur Evaluasi

\begin{tabular}{|c|c|c|c|c|c|c|c|}
\hline \multirow{2}{*}{ No } & \multicolumn{5}{|c|}{ Rerata Skor Penilai } & \multirow{2}{*}{$\begin{array}{l}\text { Rata } \\
\text { Skor }\end{array}$} & \multirow{2}{*}{$\begin{array}{l}\text { Skor } \\
\text { Total }\end{array}$} \\
\hline & DS & WI & PS & KS & GR & & \\
\hline 1 & 4,2 & 4,1 & 4,0 & 4,0 & 4,0 & 4,06 & \\
\hline 2 & 4,3 & 4,0 & 4,0 & 4,1 & 4,0 & 4,06 & \\
\hline 3 & 4,0 & 4,1 & 4,1 & 4,1 & 4,0 & 4,06 & \\
\hline 4 & 4,1 & 4,1 & 4,0 & 4,1 & 4,2 & 4,10 & \\
\hline 5 & 4,2 & 4,0 & 4,1 & 4,0 & 4,2 & 4,10 & 4,07 \\
\hline 6 & 4,0 & 4,0 & 4,2 & 4,1 & 4,1 & 4,08 & \\
\hline 7 & 4,0 & 4,2 & 4,0 & 4,1 & 4,1 & 4,08 & \\
\hline 8 & 4,1 & 4,2 & 4,0 & 4,0 & 4,0 & 4,06 & \\
\hline 9 & 4,0 & 4,1 & 4,0 & 4,2 & 4,0 & 4,06 & \\
\hline
\end{tabular}

Tabel 3 menunjukkan bahwa rerata skor total adalah 4,07. Sesuai pedoman konversi yang ditetapkan, rerata skor termasuk pada klasifikasi baik dapat digunakan melakukan evaluasi tanpa perbaikan. Hal ini memberikan indikasi bahwa tingkat keterbacaan pada prosedur evaluasi proses pembelajaran yang telah dikembangkan dapat diklasifikasikan layak atau baik.

\section{Kejelasan Instrumen Evaluasi}

Hasil penilaian uji keterbacaan instrumen evaluasi disajikan pada Tabel 4. Uji keterbacaan diarahkan pada aspek-aspek yaitu: (1) kejelasan petunjuk pengisian instrumen, (2) kelengkapan instrumen evaluasi perencanaan, (3) kelengkapan instrumen evaluasi pelaksanaan, (4) kelengkapan instrumen evaluasi penilaian, (5) kesesuaian butir instrumen dengan indikator, (6) kejelasan maksud kalimat/pernyataan instrumen, (7) penggunaan kata/istilah yang mudah dipahami oleh responden, (8) ketepatan ejaan dan tanda baca, (9) bentuk dan ukuran huruf yang digunakan pada instrumen.

Tabel 4. Rekapitulasi Hasil Uji Kejelasan Instrumen

\begin{tabular}{|c|c|c|c|c|c|c|}
\hline \multirow{2}{*}{ No } & \multicolumn{5}{|c|}{ Rerata Skor Penilai } & \multirow{2}{*}{$\begin{array}{c}\text { Rerata Skor } \\
\text { Total }\end{array}$} \\
\hline & DS & WI & PS & KS & GR & \\
\hline 1 & 4,2 & 4,1 & 4,0 & 4,0 & 4,0 & \\
\hline 2 & 4,3 & 4,0 & 4,0 & 4,1 & 4,0 & \\
\hline 3 & 4,0 & 4,1 & 4,1 & 4,1 & 4,0 & \\
\hline 4 & 4,1 & 4,1 & 4,0 & 4,1 & 4,2 & \\
\hline 5 & 4,2 & 4,0 & 4,1 & 4,0 & 4,2 & 4,07 \\
\hline 6 & 4,0 & 4,0 & 4,2 & 4,1 & 4,1 & \\
\hline 7 & 4,0 & 4,2 & 4,0 & 4,1 & 4,1 & \\
\hline 8 & 4,1 & 4,2 & 4,0 & 4,0 & 4,0 & \\
\hline 9 & 4,0 & 4,1 & 4,0 & 4,2 & 4,0 & \\
\hline
\end{tabular}

Penilaian keterbacaan instrumen menggunakan skala 5. Tabel 4 menunjukkan rerata skor total sebesar 4,05. Sesuai pedoman, rerata skor termasuk klasifikasi baik, dapat digunakan tanpa perbaikan.

\section{Kejelasan Panduan}

Uji keterbacaan panduan evaluasi diarahkan: (1) kejelasan petunjuk umum; (2) kejelasan langkah evaluasi; (3) kejelasan rekomendasi; (4) kejelasan waktu pelaksanaan evaluasi; (5) kejelasan cara pengolahan skor penilaian dan pelaporan hasil penilaian; (6) kejelasan isi panduan, (7) keefektifan kalimat/kalimat baku panduan evaluasi, (8) ketepatan penggunaan ejaan dan tanda baca, (9) penggunaan istilah yang mudah dipahami oleh responden, (10) bentuk dan ukuran huruf. Adapun hasil penilaian uji keterbacaan instrumen evaluasi disajikan pada Tabel 5 
Tabel 5. Rekapitulasi Hasil Uji Keterbacaan Panduan Evaluasi

\begin{tabular}{ccccccc}
\hline \multirow{2}{*}{ No } & \multicolumn{5}{c}{ Rerata Skor Penilai } & \multicolumn{2}{c}{ Rerata } \\
\cline { 2 - 5 } & DS & WI & PS & KS & GR & Skor Total \\
\hline 1 & 4,1 & 4,1 & 4,0 & 4,0 & 4,0 & \\
2 & 4,1 & 4,1 & 4,1 & 4,1 & 4,0 & \\
3 & 4,2 & 4,1 & 4,3 & 4,1 & 4,0 & \\
4 & 4,1 & 4,1 & 4,2 & 4,0 & 4,0 & \\
5 & 4,1 & 4,2 & 4,2 & 4,0 & 4,0 & 4,08 \\
6 & 4,2 & 4,0 & 4,1 & 4,0 & 4,1 & \\
7 & 4,0 & 4,0 & 4,1 & 4,0 & 4,0 & \\
8 & 4,0 & 4,0 & 4,2 & 4,1 & 4,1 & \\
9 & 4,0 & 4,1 & 4,1 & 4,1 & 4,1 & \\
10 & 4,0 & 4,1 & 4,0 & 4,0 & 4,1 & \\
\hline
\end{tabular}

Penilaian keterbacaan panduan menggunakan skala 5. Tabel 5 menunjukkan rerata skor total besarnya 4,08. Sesuai dengan pedoman konversi rerata skor tersebut termasuk pada klasifikasi baik atau dapat digunakan untuk melakukan evaluasi tanpa perbaikan.

\section{Validitas dan Reliabilitas Instrumen}

Pelaksanaan validasi instrumen model evaluasi proses pembelajaran matematika di SMP melalui uji coba di lapangan sebanyak tiga kali dengan jumlah responden yang semakin meningkat. Hasil validasi Ahli dan Praktisi sebagai berikut.

\section{Validitas dan Reliabilitas Instrumen}

Hasil validasi oleh pakar (ahli) dan praktisi (Guru, kepala sekolah, pengawas, widyaiswara) melalui FGD (Focus group discussion) disajikan pada Tabel 6.

Pelaksanaan validasi instrumen model evaluasi proses pembelajaran matematika di SMP melalui uji coba di lapangan sebanyak tiga kali dengan jumlah responden yang semakin meningkat, seperti pada Tabel 7.

Tabel 6. Rekapitulasi Hasil Validasi Pakar

\begin{tabular}{llcccc}
\hline \multirow{2}{*}{ No $\begin{array}{l}\text { Kompetensi } \\
\text { yang dievaluasi }\end{array}$} & \multicolumn{3}{c}{ Skor Rerata } & & \\
\cline { 3 - 4 } & Ahli & Prakt & & \\
\hline 1 & Prosedur & 4,10 & 4,18 & 4,14 & \\
2 & Instrumen & 4,16 & 4,20 & 4,18 & 4,08 \\
3 & Panduan & 4,22 & 4,11 & 4,17 & \\
\hline
\end{tabular}

Tabel 7. Rekapitulasi Hasil Validasi Pakar

\begin{tabular}{|c|c|c|c|c|c|c|}
\hline \multirow[t]{2}{*}{ Instrumen } & & \multirow[t]{2}{*}{$\mathrm{KMO}$} & \multicolumn{2}{|c|}{$\begin{array}{c}\text { Loading } \\
\text { Factor }\end{array}$} & \multirow{2}{*}{$\begin{array}{l}\text { Total } \\
\text { Var }\end{array}$} & \multirow{2}{*}{$\begin{array}{l}\text { Koef } \\
\text { Kapa }\end{array}$} \\
\hline & & & Min & $\mathrm{Mk}$ & & \\
\hline \multirow[t]{3}{*}{ Perencanaan } & 1 & 0,73 & 0,70 & 0,96 & $78 \%$ & \\
\hline & 2 & 0,84 & 0,76 & 0,97 & $87 \%$ & 0,79 \\
\hline & 3 & 0,82 & 0,75 & 0,97 & $89 \%$ & \\
\hline \multirow[t]{3}{*}{ Pelaksanan } & 1 & 0,72 & 0,65 & 0,92 & $70 \%$ & \\
\hline & 2 & 0,76 & 0,72 & 0,96 & $85 \%$ & 0,83 \\
\hline & 3 & 0,79 & 0,74 & 0,96 & $86 \%$ & \\
\hline \multirow[t]{3}{*}{ Penilaian. } & 1 & 0,71 & 0,63 & 0,96 & $80 \%$ & \\
\hline & 2 & 0,72 & 0,62 & 0,97 & $84 \%$ & 0,96 \\
\hline & 3 & 0,81 & 0,72 & 0,97 & $86 \%$ & \\
\hline
\end{tabular}

Berdasarkan tabel rekapitulasi hasil analisis instrumen evaluasi pembelajaran matematika, semua harga KMO lebih besar dari 0,5, dan semua hasil uji Bartlett,s test of Sphericity signifikan $($ sig $<0,05)$. Muatan faktor untuk semua instrumen ketiga tahap uji coba semuanya lebih besar dari 0,5 sehingga instrumen dinyatakan valid. Semua instrumen evaluasi proses pembelajaran memiliki koefisien reliabilitas di atas 0,7, untuk ketiga tahap uji coba. Dengan demikian, dapat dikatakan bahwa instrumen evaluasi perencanaan pembelajaran, instrumen evaluasi pelaksanaan proses pembelajaran, dan instrumen evaluasi pelaksanaan penilaian hasil belajar peserta didik telah memiliki validitas dan reliabilitas yang baik. Dengan demikia, telah dapat digunakan untuk mengumpulkan data.

\section{Tahap Implementasi}

Untuk mengetahui efektivitas model evaluasi proses pembelajaran matematika di SMP berdasarkan Kurikulum 2013, maka model di sebarkan kepada 20 orang guru matematika dan 15 orang kepala SMP untuk dinilai efektivitasnya. Suatu model evaluasi dikatakan efektif atau baik jika memenuhi syarat: komprehensif, praktis, ekonomis, dan didukung oleh instrumen pengumpul data yang valid dan reliabel, serta memiliki kejelasan bahasa. Untuk itu, penilaian model evaluasi proses pembelajaran matematika ini difokuskan pada kejelasan, komunikatif, komprehensif, kepraktisan, dan efisien. 
Penilaian terhadap efektivitas model evaluasi diarahkan pada: (1) kejelasan prosedur (2) kekomunikatifan bahasa yang digunakan, (3) kelengkapan komponen model evaluasi, (4) kelengkapan indikator instrumen, (5) kepraktisan panduan model evaluasi, (6) kepraktisan instrumen model evaluasi pembelajaran, (7) efisien dari segi waktu, (10) efisiensi dari segi biaya yang diperlukan, (11) efisiensi dari segi tenaga yang digunakan. Penilaian efektivitas model evaluasi proses pembelajaran menggunakan skala 5 , yaitu, 5=sangat efektif, 4=efektif, 3=cukup, $2=$ kurang efektif, dan $1=$ tidak efektif. Berdasarkan hasil penilaian $t$, dihitung skor total. Rerata skor hasil penilaian terhadap model evaluasi proses pembelajaran matematika di SMP berdasarkan Kurikulum 2013 disajikan dalam Tabel 8.

Tabel 8. Rekapitulasi Hasil Penilaian Efektivitas Model Evaluasi

\begin{tabular}{ccccccc}
\hline \multirow{2}{*}{$\begin{array}{c}\text { No } \\
\text { Aspek }\end{array}$} & \multicolumn{5}{c}{ Rerata Skor Penilai } & Rata \\
\cline { 2 - 6 } & Ds & WI & PS & KS & Guru & Skor \\
\hline 1 & 4,1 & 4,0 & 4,0 & 4,0 & 4,2 & 4,06 \\
2 & 4,0 & 4,1 & 4,1 & 4,1 & 4,1 & 4,08 \\
3 & 4,0 & 4,0 & 4,1 & 4,0 & 4,1 & 4,04 \\
4 & 4,0 & 4,1 & 4,1 & 4,1 & 4,1 & 4,08 \\
5 & 4,0 & 4,1 & 4,1 & 4,0 & 4,0 & 4,04 \\
6 & 4,1 & 4,2 & 4,0 & 4,0 & 4,1 & 4,08 \\
7 & 4,0 & 4,1 & 4,0 & 4,1 & 4,1 & 4,06 \\
8 & 4,1 & 4,1 & 4,1 & 4,0 & 4,0 & 4,06 \\
9 & 4,1 & 4,2 & 4,0 & 4,0 & 4,1 & 4,08 \\
\multicolumn{5}{c}{ Rerata Skor Total $=4,06$} \\
\hline
\end{tabular}

Berdasarkan rerata skor total 4,06 dan dikonsultasikan dengan pedoman konversi skor, masuk pada klasifikasi efektif, memberikan indikasi bahwa tingkat keterbacaan instrumen evaluasi pembelajaran yang dikembangkan dapat diklasifikasikan baik. Untuk memperoleh informasi yang akurat terhadap pelaksanaan proses pembelajaran, diperlukan instrumen pengumpul data yang valid dan reliabel. Berdasarkan hasil uji coba lapangan, ternyata instrumen yang dikembangkan dalam penelitian ini telah memiliki validitas, reliabilitas, maupun kecocokan model yang baik. Oleh karena semua per- syaratan sebagai model tergolong efektif dan telah terpenuhi, maka dapat dikatakan bahwa model evaluasi proses pembelajaran matematika sangat efektif untuk diterapkan dalam mengevaluasi proses pembelajaran matematika di SMP berdasarkan Kurikulum 2013.

\section{Simpulan dan Saran}

Simpulan

Berdasarkan hasil penelitian diperoleh simpulan sebagai berikut.

Pertama, evaluasi proses pembelajaran terdiri tiga komponen yaitu: evaluasi perencanaan pembelajaran, evaluasi pelaksanaan pembelajaran, dan evaluasi pelaksanaan penilaian hasil belajar. Komponen evaluasi perencanaan pembelajaran meliputi silabus, RPP, dan bahan ajar. Komponen evaluasi pelaksanaan pembelajaran meliputi kegiatan pendahuluan, kegiatan inti, dan kegiatan penutup. Komponen evaluasi pelaksanaan penilaian hasil belajar meliputi evaluasi perencanaan penilaian, evaluasi pelaksanaan penilaian, dan evaluasi pelaksanaan pengelolaan dan pelaporan hasil belajar peserta didik.

Kedua, kualitas panduan evaluasi dan instrumen evaluasi yang digunakan pada kategori baik. Hal ini berdasarkan hasil validasi dan estimasi reliabilitas yang dilakukan melalui FGD oleh para pakar dan praktisi.

Ketiga, panduan pelaksanaan evaluasi terdiri dari: ketentuan umum, langkah-langkah pelaksanaan evaluasi pembelajaran, pedoman penyekoran, langkah-langkah penilaian, waktu pelaksanaan evaluasi, rekomendasi hasil evaluasi, dan format laporan hasil penilaian peserta didik.

Keempat, efektivitas model dinilai dari kejelasan prosedur, bahasa yang digunakan, kekomprehensifan komponen model, kejelasan instrumen, kepraktisan panduan evaluasi, dan keekonomisan dari segi biaya, tenaga, dan waktu, termasuk kategori efektif. Penilai efektivitas model evaluasi proses pembelajaran adalah guru, kepala sekolah, dan pengawas. Jawaban atas pernyataan instrumen dinyatakan dalam bentuk skor 
dengan skala 1 sampai 5, dan hasilnya adalah: (a) kejelasan prosedur amat baik, (b) kejelasan bahasa amat baik, (c) kekomprehensifan komponen baik, (d) kejelasan indikator baik, (e) kepraktisan panduan sangat baik, (e) keekonomisan segi waktu, biaya dan tenaga sangat baik. Berdasarkan pedoman konversi, rerata skor seluruhnya pada kategori sangat baik. (5) Model evaluasi proses pembelajaran yang dikembangkan sudah baik dan efektif berdasarkan penilaian para pakar, praktisi dan pengguna model.

Saran

Berdasarkan simpulan tersebut disampaikan saran-saran sebagai berikut: (1) Evaluasi model yang dikembangkan dapat dijadikan model untuk mengevaluasi pelaksanaan pembelajaran matematika di SMP berdasarkan Kurikulum 2013; (2) dalam melakukan evaluasi terhadap proses pembelajaran matematika di sekolah, evaluator melakukan kegiatan pengamatan secara terprogram; (3) Sebelum evaluasi model P3 digunakan, sebaiknya terlebih dahulu dilakukan desiminasi secara luas, yang melibatkan pihakpihak terkait, baik kepada kepala sekolah, guru, pengawas, LPMP, maupun pihak Dinas Pendidikan; (4) Model evaluasi P3 akan lebih lengkap jika dikembangkan dengan komponen produk, sebagai dasar pengambilan keputusan/kebijakan; (5) Model evaluasi ini akan lebih menarik apabila dikembangkan lebih lanjut dengan pembuatan program komputer sehingga seorang evaluator hanya mengoreksi data yang ada dan mengentrinya ke dalam program. Selanjutnya, evaluator tinggal mengambil print-out berupa hasil evaluasi dan rekomendasi hasil evaluasi dalam rangka perbaikan proses pembelajaran.

\section{Daftar Pustaka}

Borg, W. R., \& Gall, M.D. (2003). Educational research: An Introduction. Fourth edition. New York: Longman.

Daley, G \& Kim, L. (2010). A teacher evaluation system that works. National Institute for Excelent in Teaching.
Darling-Hammond, L. (2010). Evaluating Teacher Effectiveness. http://www.google.co.id/url.

Darmadi, H. (2012). Kemampuan dasar mengajar: Landasan konsep dan implementasi. Bandung: Alfabeta.

Depdikbud. (2013). Permendikbud Nomor 54 tentang Standar kompetensi Lulusan. Jakarta: Pusat Kurikulum Depdikbud

Depdikbud. (2013). Permendikbud Nomor 65 tentang Standar Proses. Jakarta: Pusat Kurikulum Depdikbud.

Depdikbud. (2013). Permendikbud Nomor 66 tentang Standar Penilaian. Jakarta: Pusat Kurikulum Depdikbud.

Depdikbud. (2013). Permendikbud Nomor 68 tentang Kerangka Dasar dan Struktur Kurikulum SMP/MTs. Jakarta: Pusat Kurikulum Depdikbud.

Depdikbud. (2013). Permendikbud Nomor $81 A$ tentang Implementasi Kurikulum 2013. Jakarta: Pusat Kurikulum Depdikbud.

Fitzpatrick, J.L., Sander, J. R.,\& Worthen, B.L., (2011). Program evaluation: alternative approaches and pratical guidelines. Boston: Pesron.

Fleiss, J.L., Levin,B., \& Paik, M.C. (2003). Statistical methods for retes and proportions $\left(3^{\text {rd }}\right)$. New Jersey: John Wiley \& Sons, Inc, Publication.

Gronlund \& Linn. (1985). Measurement and evaluating teaching: $6^{\text {th }}$ Edition. New York: Macmillan Publishing Company.

Gwet, K. L. (2012). Handbook of inter-rater reliability. Third edition Advanced Analytics,LLC Gaithersburg, USA

Hood, S., \& Hopson. R. K. (2008). Evaluation roots reconsidered: Asa Hilliard" Nobody Knows My Name" project, and African Educational Exellence. Review of Education Research, $78,410-426$. 
Howell, K.W \& Nolet, V. (2000). Curriculum based evaluation: teaching and decision making. Canada: Wadswortth Thomson Learning.

Kartowagiran, B., Jaedun, A., \& Retnawati, H. (2013). Kesiapan SMP di Daerah Istimewa Yogyakarta untuk menmgimplementasikan kurikulum 2013. Penelitian PEP, Program Pascasarjana Universitas Negeri Yogyakarta.

Kaufman, R., \& Thomas, S. (1980). Evaluation without fear. New York: New Viewpoints.

Linn, R. L. (ed) (1989) Educational measurement $\left(3^{\text {th }}\right)$. New York: American Council on Education/Mac-millan Publishing Company.

Majid, A. (2008). Perencanaan Pembelajaran. Bandung: Remaja Rosdakarya

Martiyono. (2012). Perencanaan Pembelajaran Yogyakarta : Aswaja Presindo
Nitko, A.J, \& Brookhart S.M. (2007). Educational asessment of students. Ohio: Pearson (Merril Prentice New Jersey: Pearson Education.

Rusman. (2012). Manajemen kurikulum. Jakarta: Raja Grafindo Persada.

Stufflebeam, L.D., Madaus, G.F., \& Kellaghan, T.(2002). Evaluation models: viewpoints on educational and buman services evaluation. Dordrecht; Kluwer Academic Publisher

Suherman, E. (2003). Strategi Pembelajaran Kontemporer. Bandung: Jurusan Pend Matematika Fakultas Pendidikan MIPA, Universitas Pendidikan Indonesia.

Sudijono, A. (2011). Pengantar evaluasi pendidikan. Jakarta: PT Raja Grafindo Persada.

Uno, H. B. (2008). Perencanaan pembelajaran. Jakarta: PT Bumi Aksara. 